\title{
Cytomegalovirus mRNA
}

National Cancer Institute

\section{Source}

National Cancer Institute. Cytomegalovirus mRNA. NCI Thesaurus. Code C113509.

Any RNA molecule expressed by a cytomegalovirus strain that contains protein-coding

information in its nucleotide sequence that can be translated into the amino acid sequence of a protein. 